University of Nebraska - Lincoln

DigitalCommons@University of Nebraska - Lincoln

Nebraska Cooperative Fish \& Wildlife Research Nebraska Cooperative Fish \& Wildlife Research Unit -- Staff Publications

2008

Flower power: tree flowering phenology as a settlement cue for migrating birds

\author{
Laura J. McGrath \\ US Geological Survey \\ Charles van Riper III \\ US Geological Survey \\ Joseph J. Fontaine \\ US Geological Survey, jfontaine2@unl.edu
}

Follow this and additional works at: https://digitalcommons.unl.edu/ncfwrustaff

Part of the Other Environmental Sciences Commons

McGrath, Laura J.; van Riper, Charles III; and Fontaine, Joseph J., "Flower power: tree flowering phenology as a settlement cue for migrating birds" (2008). Nebraska Cooperative Fish \& Wildlife Research Unit -Staff Publications. 59.

https://digitalcommons.unl.edu/ncfwrustaff/59

This Article is brought to you for free and open access by the Nebraska Cooperative Fish \& Wildlife Research Unit at DigitalCommons@University of Nebraska - Lincoln. It has been accepted for inclusion in Nebraska Cooperative Fish \& Wildlife Research Unit -- Staff Publications by an authorized administrator of DigitalCommons@University of Nebraska - Lincoln. 


\title{
Flower power: tree flowering phenology as a settlement cue for migrating birds
}

\author{
Laura J. McGrath ${ }^{1,2}$, Charles van Riper III ${ }^{1}$ and Joseph J. Fontaine ${ }^{1, *}$ \\ ${ }^{1}$ US Geological Survey Southwest Biological Science Center, Sonoran Desert Research Station, University of Arizona, \\ Tucson, AZ 85721, USA; and 2 Department of Biological Science, Northern Arizona University, Flagstaff, AZ 86011, USA
}

\begin{abstract}
Summary
1. Neotropical migrant birds show a clear preference for stopover habitats with ample food supplies; yet, the proximate cues underlying these decisions remain unclear.

2. For insectivorous migrants, cues associated with vegetative phenology (e.g. flowering, leaf flush, and leaf loss) may reliably predict the availability of herbivorous arthropods. Here we examined whether migrants use the phenology of five tree species to choose stopover locations, and whether phenology accurately predicts food availability.

3. Using a combination of experimental and observational evidence, we show migrant populations closely track tree phenology, particularly the flowering phenology of honey mesquite (Prosopis glandulosa), and preferentially forage in trees with more flowers. Furthermore, the flowering phenology of honey mesquite reliably predicts overall arthropod abundance as well as the arthropods preferred by migrants for food.

4. Together, these results suggest that honey mesquite flowering phenology is an important cue used by migrants to assess food availability quickly and reliably, while in transit during spring migration.
\end{abstract}

Key-words: foraging, habitat selection, migration, phenology, stopover

\section{Introduction}

Migration is an energetically demanding period in the annual cycle of many species of birds, and can impose strong selection on individuals and represent an important limitation to population viability (Lindström 1989; Marra, Hobson \& Holmes 1998; Sillet \& Holmes 2002; Heglund \& Skagen 2005; Lind \& Cresswell 2006; Newton 2006). Because of their small size and long-distance migration, Neotropical migrant songbirds are unable to carry sufficient energy reserves to migrate nonstop and must select habitats en route to stop and refuel (Moore \& Aborn 2000). Stopover site selection directly influences survival and has cascading effects on future reproduction (Piersma 1990; Moore et al. 1995; Moore, Smith \& Sandberg 2005); yet during migration, most individuals are in unfamiliar surroundings and have limited time and energy to sample habitats (Hutto 1985a; Loria \& Moore 1990; Moore, Kerlinger \& Simons 1990; Moore \& Yong 1991; Moore \& Aborn 2000; Petit 2000). Food limitation, predation, competition, and unfavourable weather all represent important costs associated with selecting stopover locations (Moore et al. 1995, 2005; Petit 2000) and theory would predict that birds should choose locations that minimize these costs (Fretwell \& Lucas 1970; Fretwell 1972; Houston 1998).
However, despite clear evidence that migrants exhibit habitat preference during stopover (Hutto 1985a; Moore et al. 1995, 2005), we know little about the ecological cues individuals use to select stopover locations (Petit 2000).

Variation in food resources, for example, can profoundly affect risk of starvation, exposure to predation, breeding energy budgets, and timing of breeding (Lima \& Dill 1990; Piersma 1990; Moore et al. 1995, 2005; Newton 2006). Birds clearly prefer habitats that maximize the availability of food resources (Hutto 1985a; Moore et al. 1995), yet the cues that birds use to select these habitats remain largely unknown. Although direct sampling of food availability is the most accurate method of determining habitat suitability, the time and energy constraints migrants face may limit them to using vegetative and structural cues (Moore \& Aborn 2000). Available foliage is generally correlated with the diversity and abundance of herbivorous insects (Marques, Price \& Cobb 2000; Murakami, Hirao \& Ichie 2007); therefore, changes in tree phenology (e.g. flowering, leaf flush, and leaf loss) may present insectivorous migrant birds with structural cues that reliably predict food availability.

Here we used observational and experimental evidence to examine whether insectivorous Neotropical migrant birds use tree phenology to choose stopover locations and if phenology accurately predicts food availability. Specifically, we asked: (i) Are macrohabitat patterns of avian diversity and abundance 
Table 1. Study species and sample sizes

\begin{tabular}{|c|c|c|c|c|c|c|c|}
\hline & \multirow[b]{2}{*}{ Family } & \multicolumn{2}{|l|}{ Name } & \multirow[b]{2}{*}{ Code* } & \multirow[b]{2}{*}{ Count $\dagger$} & \multirow[b]{2}{*}{ Forage: } & \multirow[b]{2}{*}{ Arthropod } \\
\hline & & Scientific & Common & & & & \\
\hline \multirow[t]{28}{*}{ Bird Species } & \multirow[t]{5}{*}{ Tyrannidae } & Tyrannus verticalis & Western kingbird & WEKI & 141 & - & - \\
\hline & & Myiarchus cinerascens & Ash-throated flycatcher & ATFL & 334 & 1 & - \\
\hline & & Empidonax wrightii & Gray flycatcher & GRFL & 14 & - & - \\
\hline & & Empidonax difficilis & Pacific-slope flycatcher & PSFL & 83 & 1 & 10 \\
\hline & & Empidonax occidentalis & Cordilleran flycatcher & COFL & & & \\
\hline & Regulidae & Regulus calendula & Ruby-crowned kinglet & RCKI & 176 & 2 & - \\
\hline & \multirow[t]{3}{*}{ Turdidae } & Turdus migratorius & American robin & AMRO & 61 & - & - \\
\hline & & Catharus guttatus & Hermit thrush & HETH & 11 & - & - \\
\hline & & Catharus ustulatus & Swainson's thrush & SWTH & 4 & - & - \\
\hline & \multirow[t]{3}{*}{ Vireonidae } & Vireo plumbeus & Plumbeous vireo & PLVI & 10 & - & - \\
\hline & & Vireo gilvus & Warbling vireo & WAVI & 48 & 20 & 3 \\
\hline & & Vireo bellii & Bell's vireo & BEVI & 170 & 2 & - \\
\hline & \multirow[t]{12}{*}{ Parulidae } & Vermivora ruficapilla & Nashville warbler & NAWA & 72 & 55 & 13 \\
\hline & & Vermivora celata & Orange-crowned warbler & OCWA & 159 & 92 & 14 \\
\hline & & Wilsonia pusilla & Wilson's warbler & WIWA & 200 & 122 & 26 \\
\hline & & Dendroica nigrescens & Black-throated grey warbler & BTYW & 43 & 28 & 2 \\
\hline & & Vermivora luciae & Lucy' warbler & LUWA & 412 & 16 & - \\
\hline & & Oporornis Philadelphia & MacGillivary's warbler & MGWA & 29 & 8 & 5 \\
\hline & & Dendroica townsendi & Townsend's warbler & TOWA & 34 & 24 & 5 \\
\hline & & Dendroica occidentalis & Hermit warbler & HEWA & 15 & 10 & - \\
\hline & & Dendroica petechia & Yellow warbler & YWAR & 230 & 6 & 2 \\
\hline & & Dendroica coronata & Yellow-rumped warbler & YRWA & 547 & 76 & 3 \\
\hline & & Geothlypis trichas & Common yellowthroat & COYE & 340 & - & - \\
\hline & & Ictera virens & Yellow-breasted chat & YBCH & 219 & 1 & - \\
\hline & Oriolidae & Icterus bullockii & Bullock's oriole & BUOR & 188 & - & - \\
\hline & \multirow[t]{2}{*}{ Thraupidae } & Piranga ludoviciana & Western tanager & WETA & 45 & - & - \\
\hline & & Piranga rubra & Summer tanager & SUTA & 23 & - & - \\
\hline & Cardinalidae & Passerina amoena & Lazuli bunting & LABU & 14 & - & - \\
\hline \multirow[t]{5}{*}{ Tree Species } & \multirow[t]{2}{*}{ Salicaceae } & Populous fremontii & Fremont cottonwood & FRCO & 7700 & - & 59 \\
\hline & & Salix goodingii & Gooding's willow & GOWI & 4200 & - & 59 \\
\hline & \multirow[t]{2}{*}{ Fabaceae } & Prosopis pubescens & Screwbean mesquite & SCME & 7800 & - & 60 \\
\hline & & Prosopis glandulosa & Honey mesquite & HOME & 7800 & - & 71 \\
\hline & Tamaricaceae & Tamarix sp. & Tamarisk & TAMA & 7500 & - & 60 \\
\hline
\end{tabular}

*Species codes used for labels in all figures are based on common names following the American Ornithological Union. Columns denote sample sizes for point counts and tree phenology†, avian behavioural observations $\ddagger$, and lavage and tree insect sampling§.

correlated with seasonal variation in tree phenology? (ii) Do migrant birds prefer particular phenological cues when selecting foraging microhabitats? and (iii) Do these cues accurately predict food availability?

\section{Methods}

\section{STUDY SYTEM AND SPECIES}

We examined the role of tree phenology in avian habitat selection between March and May of 2001 to 2004 at Cibola National Wildlife Refuge along the lower Colorado River. We established a study site along the riparian corridor, dominated by five tree species ( $40 \% \mathrm{FRCO}$, 25\% HOME, 17\% SCME, 7\% GOWI, 11\% TAMA) and seasonally occupied by $>100$ species of migrant birds of which we focused on 28 species of insectivorous Neotropical migrant songbirds (Table 1).

\section{MACROHABITAT PREFERENCE}

To assess the ability of the avian community to use tree phenology as a settlement cue, we established two 1-km transects through the middle of the study area, separated by $300 \mathrm{~m}$. Transects did not differ in vegetation and here are not considered independent samples, but rather a means of assuring overlap between estimates of avian abundance and stand phenology. Each week, the same observer walked both transects visually sampling 100 trees of each species found within $50 \mathrm{~m}$. At each tree, we calculated phenology by visualizing a full crown and estimating the proportion of the tree currently covered by leaves, flowers, and fruits. We then averaged data for each species to obtain weekly stand conditions (after van Riper 1980). To increase rigor, we also documented phenology using a digital camera, but since both methods produced similar results $\left(t_{50}=14 \cdot 38, P=0 \cdot 17\right)$, we present the larger samples based on visual estimates. Simultaneously, we conducted 25-m fixed-radius point counts (Hutto, Pletschet \& Hendricks 1986) from sunrise to $09.00 \mathrm{~h}$ at eight points along each transect. To minimize bias, we reversed starting points for avian counts and tree phenology weekly. We tested for correlations between phenology and raw estimates of avian diversity and abundance using a combination of Pearson correlations and general linear models (GLM) that included migrant species, year, and transect as factors and date as a covariate. We excluded nonsignificant interactions from trial models and corrected for multiple tests using a Bonferroni correction. 

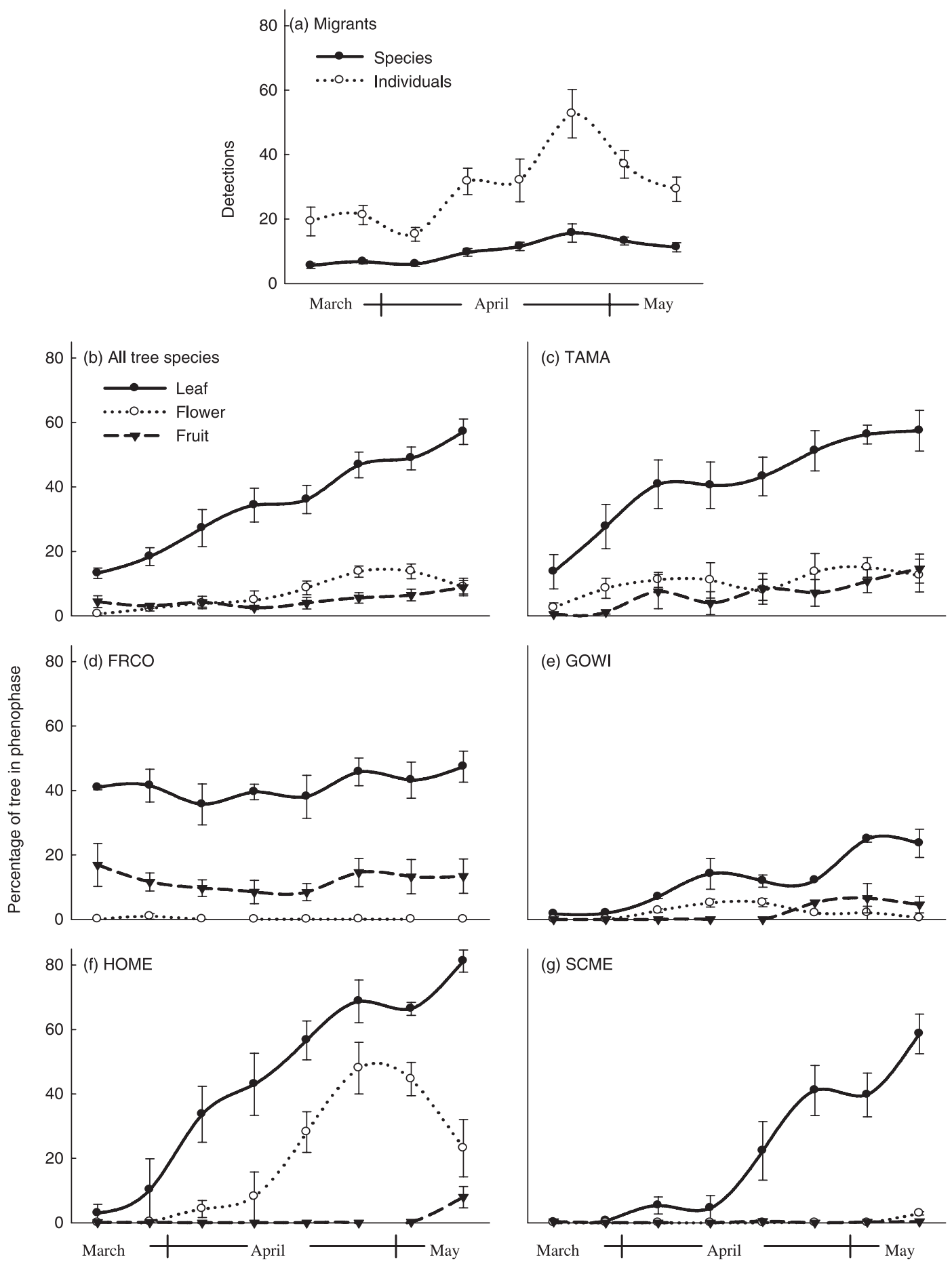

Fig. 1. Tree phenology and migrant diversity and abundance change in concert. Tree species expressed diverse phenological patterns, but generally, leaf, flower, and fruit development were highly correlated (b-g). While migrant diversity and abundance (a) correlated with the average leaf and flower phenology of all tree species (b), only the flowering phenology of honey mesquite (f) predicted migrant diversity and abundance independently. For ease of comparison, graphs present mean phenology and migrant diversity and abundance of eight periods throughout the spring, but analyses were conducted on raw data. Error bars indicate SEM across years.

\section{MICROHABITAT PREFERENCE}

To assess microhabitat preferences, we sampled individual birds along the same transects used for point-count sampling and compared the tree species and phenological conditions of migrant foraging locations against the average weekly phenology (see above) and availability of that tree species based on percentage coverage (i.e. use vs. availability). We compared the location of the first-attack manoeuver, as opposed to the location of first detection, because attack manoeuvers specifically identify foraging location, serve as independent observations (Bell, Hejl \& Verner 1990), and reduce bias associated with variation in tree architecture, (Sturman 1968; 

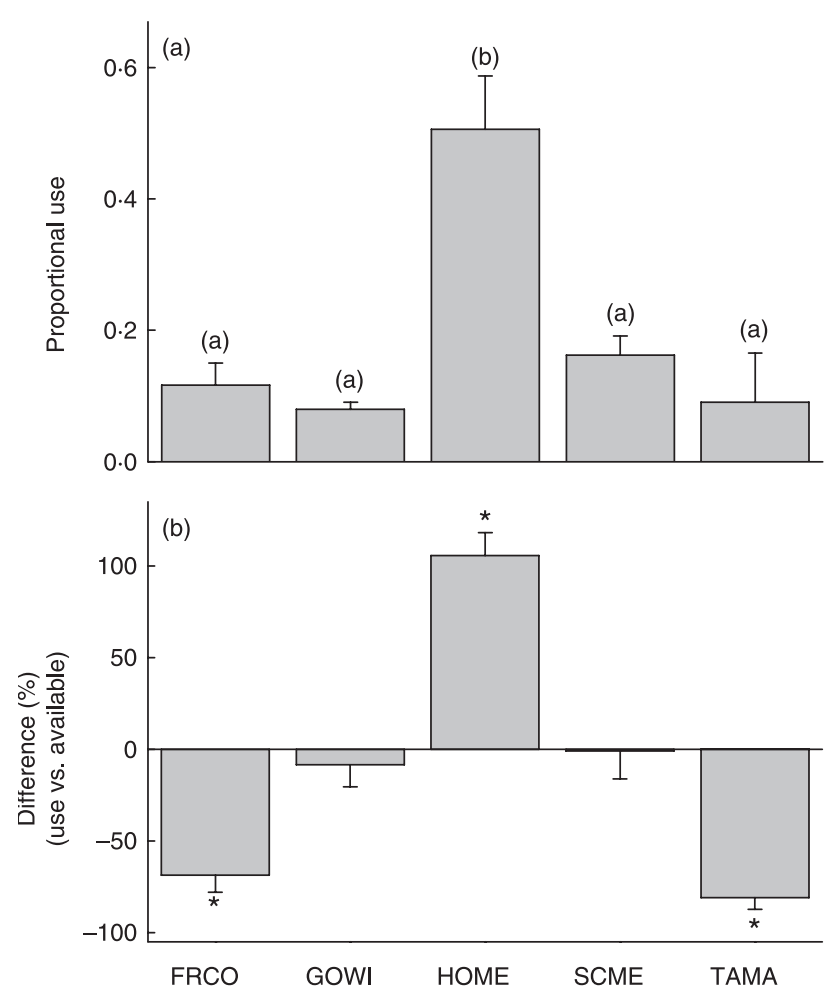
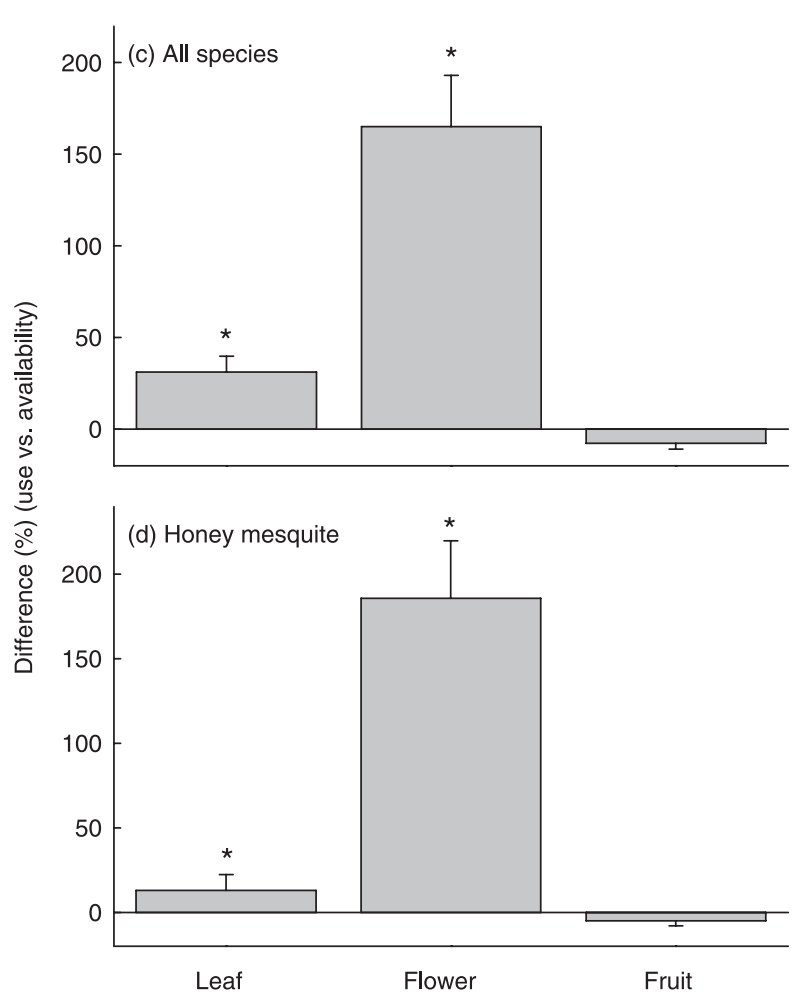

Fig. 2. Migrants prefer honey mesquite with more flowers. Migrants preferentially foraged on honey mesquite over other species (a) and more than expected given their abundance (b). While migrants were more likely to forage on trees with more leaves and flowers (c), only the leaf and flower phenology of honey mesquite predicted microhabitat preferences (d). Responses (b-d) are illustrated by percent preference $\{[($ useavailable)/available] $\times 100\}$ for ease of comparison, but all analyses were conducted on raw data. Columns denoted by different letters are significantly different at the $0 \cdot 05$ level according to an LSD post-hoc test and columns denoted by an asterisk indicate use is significantly different from availability. Error bars indicate SEM across years.

Hertz, Remsen \& Zones 1976; Bradley 1985). We tested for differences in tree species preferences using a GLM that included migrant species and year as factors and date as a covariate with least significant difference (LSD) post-hoc tests to identify differences among tree species. We also tested for differences in tree species use vs. availability using a paired $t$-test of the average preferences and availability of each tree species for each sampling period in each year. We examined phenophase preferences for all tree species and each tree species individually using a binary logistic regression, where selected tree vs. nonselected tree was the dependent variable, the three phenophase traits and date were continuous factors, and year and migrant species were included as categorical factors. We excluded nonsignificant interactions from trial models and corrected for multiple tests using a Bonferroni correction.

\section{FOOD AVAILABLITY AND USE}

We compared food availability among tree species by sampling branches from the five dominant tree species for arthropods three times in 2003 (April 3, 18; May 6). Branches (1-2.5 cm diameter, 50$70 \mathrm{~cm}$ long) were selected within the preferred foraging height of migrants within each tree species (van Riper, unpublished data), and selected branches were removed from the tree, vigorously shaken into a large plastic bag, and visually inspected for hidden arthropods (after Johnson 2000). Because migrants do not forage on all arthropods, we identified preferred species by sampling the diet of a subset of migrants captured by passive mist netting, using a modified lavage technique which has been proven effective in sampling both hard- and soft-bodied arthropods (Moody 1970; Tomback 1975; Rosenberg \& Cooper 1990; Poulin, Lefebvre \&McNeil 1994). We tested for the influence of tree species and phenology on total arthropod and preferred arthropods abundance using a combination of Pearson correlations and a GLM that included date as a covariate with LSD post-hoc tests to identify differences among tree species. We performed all tests at the lowest taxonomic identification (e.g., morpho-species) and excluded nonsignificant interactions from trial models.

\section{EXPERIMENTAL MANIPULATION OF PHENOLOGY}

The timing of leafing, flowering, and fruiting are highly correlated and their relative importance as cues for habitat selection are difficult to discern from observational data alone. For example, in honey mesquite the timing of leafing and flowering often overlap, limiting our ability to identify which cue birds may use to choose foraging locations. To separate among alternative cues, in 2003 we experimentally manipulated the flowering phenology of one of two paired honey mesquite trees. We randomly selected 17 pairs of honey mesquite in full bloom $(<10 \mathrm{~m}$ apart $)$ and reduced flower coverage on one, creating two phenology categories: light flower $(<5 \%$ coverage) and heavy flower ( $>30 \%$ coverage). Trees were deflowered by pulling petals by hand, being careful to remove the cue (i.e. the flower), but not the available arthropods, and were continually manipulated throughout the sampling period to maintain light flowering levels.

For each experimental pair, we measured migrant preference by recording the number of birds that visited each tree within a 15-min observation period between sunrise and $09.00 \mathrm{~h}$. We monitored 


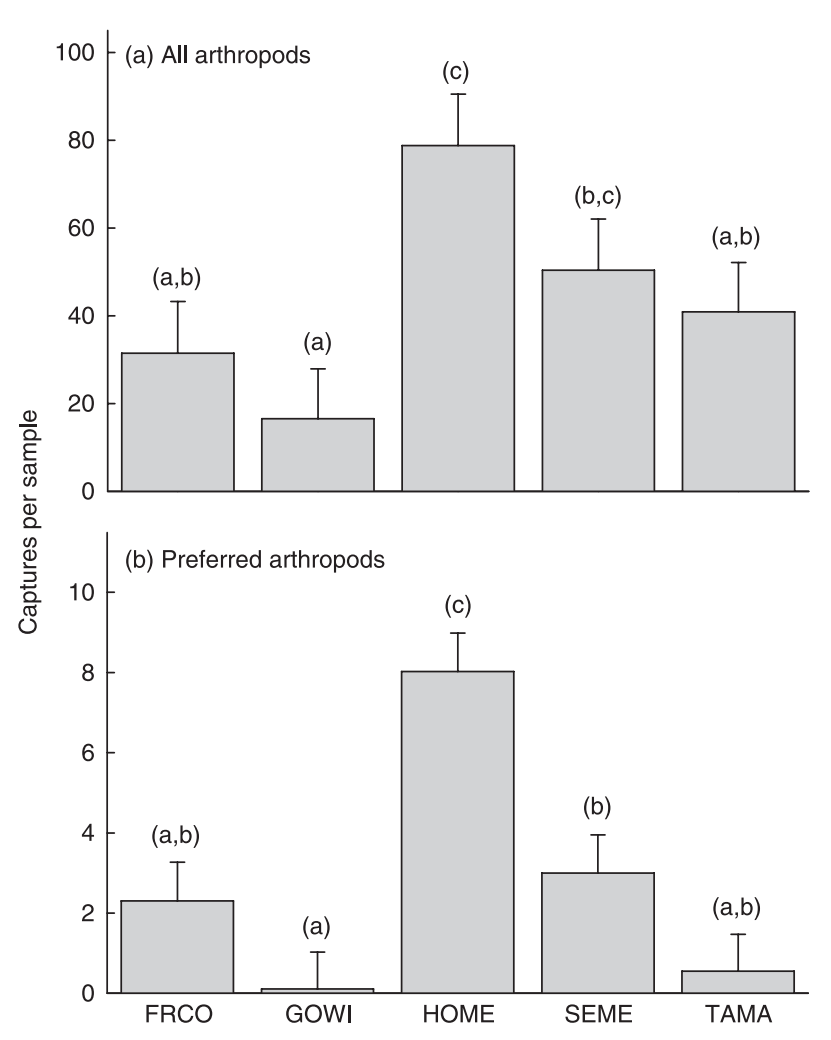

Fig. 3. Food availability is greater on honey mesquite. Total arthropod abundance was greater on honey mesquite, but not significantly (a); however, when only considering preferred foods, arthropod abundance was significantly greater on honey mesquite (b). Columns represent estimated marginal means after controlling for flower phenology. Columns denoted by different letters are significantly different at the 0.05 level according to an LSD post-hoc test.

visitation rate because it indicates a proximate preference for a particular tree type and is known to correlate with food availability (Hutto 1990) enabling us to isolate the effects of removing the settlement cue. Because migrants remain on site for $<48$ h (K.L. Paxton, C. van Riper \& C. O'Brien, unpublished), we were able to resample experimental pairs every 3 days without fear of pseudoreplication. We tested for the influence of our experimental treatment on flower and leaf phenology as well as migrant visitation using a GLM that included tree pair as factors and date as a covariate. We excluded all nonsignificant interactions from trial models.

\section{Results}

\section{MACROHABITAT PREFERENCE}

All five tree species expressed unique patterns of phenology, but generally phenological traits were positively correlated (Fig. 1; all leaf-all flower: Pearson $_{26}=0.809, P<0.001$; all leaf-all fruit: Pearson $26=0.583, P=0.002$; all flower-all fruit: Pearson $\left._{26}=0 \cdot 499, P=0 \cdot 009\right)$. Migrant diversity and abundance were positively correlated with the combined flower phenology of all tree species (Fig. 1; diversity: all flower: $F_{1,26}=13.049, P=0.02$; date $F_{1,26}=0.035, P=0.853$; year:
$F_{3,26}=4 \cdot 693, P=0 \cdot 012$; abundance: all flower: $F_{1,26}=8 \cdot 024$, $P=0.010$; date $F_{1,26}=0.406, P=0.531$; year: $F_{3,26}=1.998$, $P=0 \cdot 147$ ). However, when examined independently, only the flowering phenology of honey mesquite correlated with both diversity and abundance of migrants (Fig. 1; diversity: HOME flower: $F_{1,26}=18.447, \quad P<0.001$; date $F_{1,26}=0.566, \quad P=0.461 ;$ year: $F_{3,26}=5.099, \quad P=0.009$; abundance: HOME flower: $F_{1,26}=9.622, P=0.006$; date $F_{1,26}=0.085, P=0.773$; year: $\left.F_{3,26}=1.916, \quad P=0 \cdot 159\right)$, although the flowering phenology of screwbean mesquite did correlate with diversity (diversity: SCME flower: $F_{1,26}=13 \cdot 418, P=0 \cdot 002$; date $F_{1,26}=2 \cdot 131, P=0 \cdot 161$; year: $\left.F_{3,26}=2 \cdot 741, P=0 \cdot 072\right)$.

\section{MICROHABITAT PREFERENCE}

At the microhabitat level, tree species also significantly influenced migrant foraging decisions (tree: $F_{4,20}=21 \cdot 540$, $P<0.001$; year: $\left.F_{3,20}=0.621, P=0 \cdot 15\right)$, as migrants were found on honey mesquite more than other species (Fig. 2a) and more than availability would predict (Fig. 2b; HOME: $t_{3}=5 \cdot 299, P=0 \cdot 013 ;$ FRCO: $t_{3}=-6 \cdot 587, P=0 \cdot 008$; TAMA: $\left.t_{3}=-7 \cdot 87, P=0 \cdot 006\right)$. Migrants also preferred trees of all species that had more leaves and flowers (Fig. 2c; all leaf: Wald $_{1}=28 \cdot 143, \quad P<0.001 ;$ all flower: Wald $_{1}=40 \cdot 254$, $P<0.001$; all fruit: Wald $_{1}=0.914, \quad P=0.339$; year: Wald $_{1}=4.426, P=0.035$; date: Wald $_{1}=16.748, P<0.001$; tree species: Wald $_{4}=20.502, P<0.001$; migrant species: Wald $_{13}=5 \cdot 253, P=0.969$ ), but similar to macrohabitat patterns, when examined independently, only the phenology of honey mesquite was positively correlated with microhabitat preferences (Fig. 2d; HOME leaf: Wald $_{1}=14.598$, $P<0.001$; HOME flower: Wald $_{1}=16.599, P<0 \cdot 001$; HOME fruit: $\quad$ Wald $_{1}=1.441, \quad P=0.230 ; \quad$ year: $\quad \operatorname{Wald}_{1}=0.772$, $P=0 \cdot 380$; date: Wald $_{1}=6 \cdot 320, P=0 \cdot 012$; migrant species: Wald $\left._{11}=0 \cdot 781, P=1 \cdot 000\right)$.

\section{FOOD AVAILABLITY AND USE}

We collected 172 different morpho-species representing 12 orders; however, migrant stomach contents included only nine orders of which five morph-species (preferred arthropods) made up $>25 \%$ of their total diet. Tree species (Fig. 3 ) and phenology (Fig. 4) influenced both total (tree species: $F_{4,309}=3 \cdot 514, P=0 \cdot 008$; leaf: ${ }_{1,309}=1 \cdot 311, P=0 \cdot 253$; flower: $\left.F_{1,309}=61 \cdot 274, P<0 \cdot 001\right)$ and preferred arthropod abundance (tree species: $F_{4,309}=5 \cdot 962, P<0 \cdot 001$; leaf: ${ }_{1,309}=2 \cdot 757$, $P=0.098$; flower: $\left.F_{1,309}=50 \cdot 139, P<0.001\right)$; however, only preferred arthropod abundance differed between tree species (Fig. 3b). When examined independently, total arthropod abundance was positively correlated with the flowering phenology of three of the five tree species (HOME flower: $F_{1,70}=18 \cdot 549, P<0 \cdot 001$; GOWI flower: $F_{1,59}=30 \cdot 929, P<0 \cdot 001$; TAMA flower: $\left.F_{3,60}=21.771, P<0.001\right)$, but preferred arthropod abundance was only correlated with the flowering phenology of honey mesquite (Fig. 4d; HOME flower: $\left.F_{1,70}=30 \cdot 752, P<0 \cdot 001\right)$. 

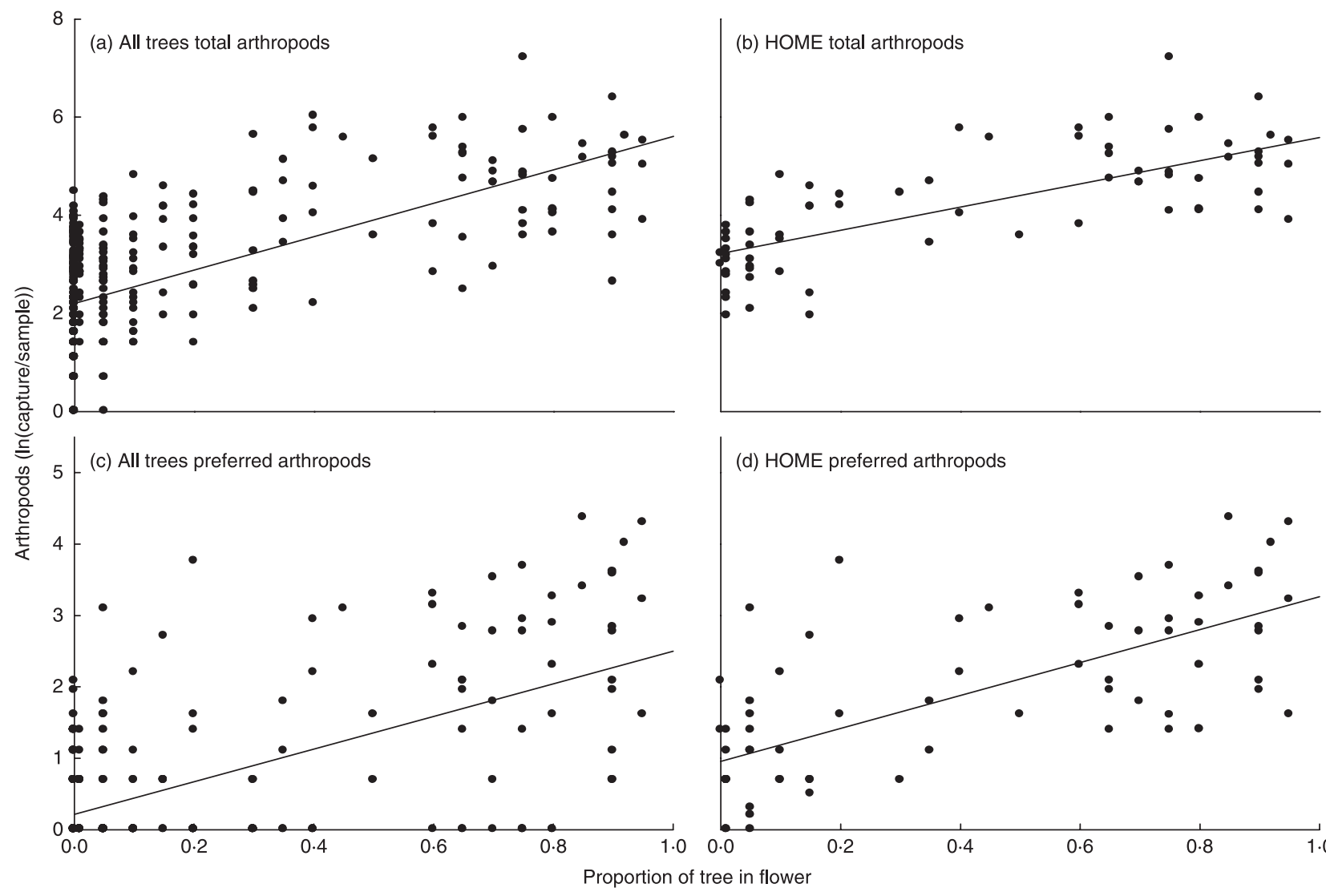

(d) HOME preferred arthropods

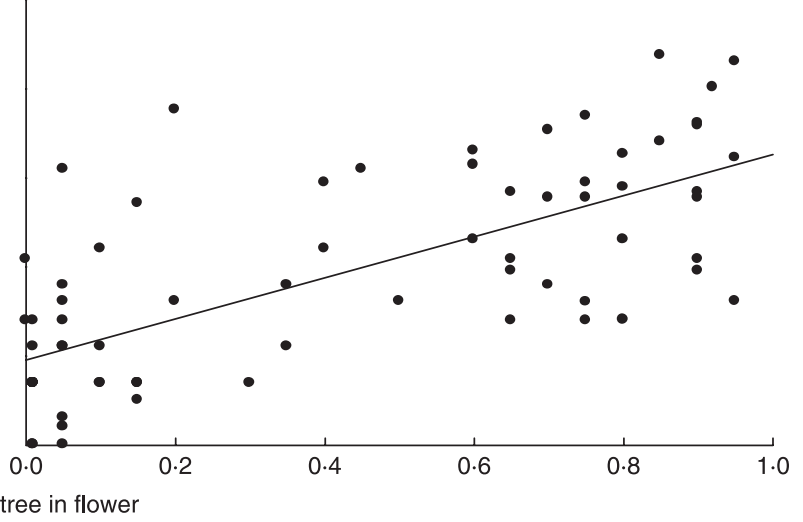

Fig. 4. Food availability increases with flower coverage. While total arthropod abundance (a) and preferred arthropod abundance (c) correlated with the average flower phenology of all tree species (b), only the flowering phenology of honey mesquite (b, d) predicted both total and preferred arthropod abundance independently. For ease of comparison, arthropod abundance is presented as $\ln ($ capture/sample), but all analyses were conducted on raw data.

\section{EXPERIMENTAL MANIPULATION OF PHENOLOGY}

Experimental manipulations significantly reduced flower coverage (Fig. 5a; treatment: $F_{1,128}=530 \cdot 226, P<0 \cdot 001$; tree pair: $F_{16,128}=2 \cdot 430, P=0.004$; date: $F_{1,128}=14 \cdot 231, P<0.001$, but not leaves (Fig. 5a; treatment: $F_{1,128}=1 \cdot 253, P=0 \cdot 265$; tree pair: $F_{16,128}=4.015, P<0.001$; date: $F_{1,128}=91 \cdot 801, P<0.001$ ) and resulted in a significant decrease in visitation rate of migrants (Fig. 5b; treatment: $F_{1,128}=28.094, P<0.001$; tree pair: $F_{16,128}=1 \cdot 757, P=0 \cdot 047$; date: $\left.F_{1,128}=2 \cdot 142, P=0 \cdot 146\right)$.

\section{Discussion}

Migration is an important component of the life history of migratory birds, and for species that do not migrate continuously, where they stop to rest and refuel can have important implications for future survival and reproduction (Piersma 1990; Moore et al. 1995, 2005; Petit 2000). Yet, despite the importance of stopover decisions to avian life-history evolution and migratory bird conservation, we know little about how birds select stopover habitats. Predation and competition may shape stopover decisions, but food availability likely determines habitat preference (Hutto 1985a; Petit 2000; Moore et al. 2005). Birds are sensitive to food availability
(Morris et al. 1958; MacArthur \& Pianka 1966; Zach \& Falls 1976) and can preferentially settle in food-rich environments (e.g. Hutto 1980; Yard et al. 2004); yet, the cues underlying these decisions remain unclear. Using both observational and experimental evidence, we show for the first time that the flowering phenology of a common tree species, honey mesquite, acts as a reliable settlement cue for insectivorous Neotropical migrant birds at both the macro- and microhabitat levels.

Although we examined the phenology of all five major tree species along the Lower Colorado River, only the flowering phenology of honey mesquite consistently predicted seasonal variation in migrant diversity and abundance (Fig. 1). Mesquite flowers are highly visible and therefore may reduce search time in unfamiliar habitats. Furthermore, total and preferred arthropod abundance correlated with the flowering phenology of honey mesquite (Fig. 4), indicating the reliability of flowers as a settlement cue and implying that migratory timing and routes may have evolved to exploit this readily available and explicitly advertised resource. Indeed, exploitation of high elevation and monsoon-dependent habitats by fall migrant populations (e.g. DeLong, Cox \& Cox 2005) suggests that stopover habitat preferences may be highly dependent upon area phenology. Alternatively, since 

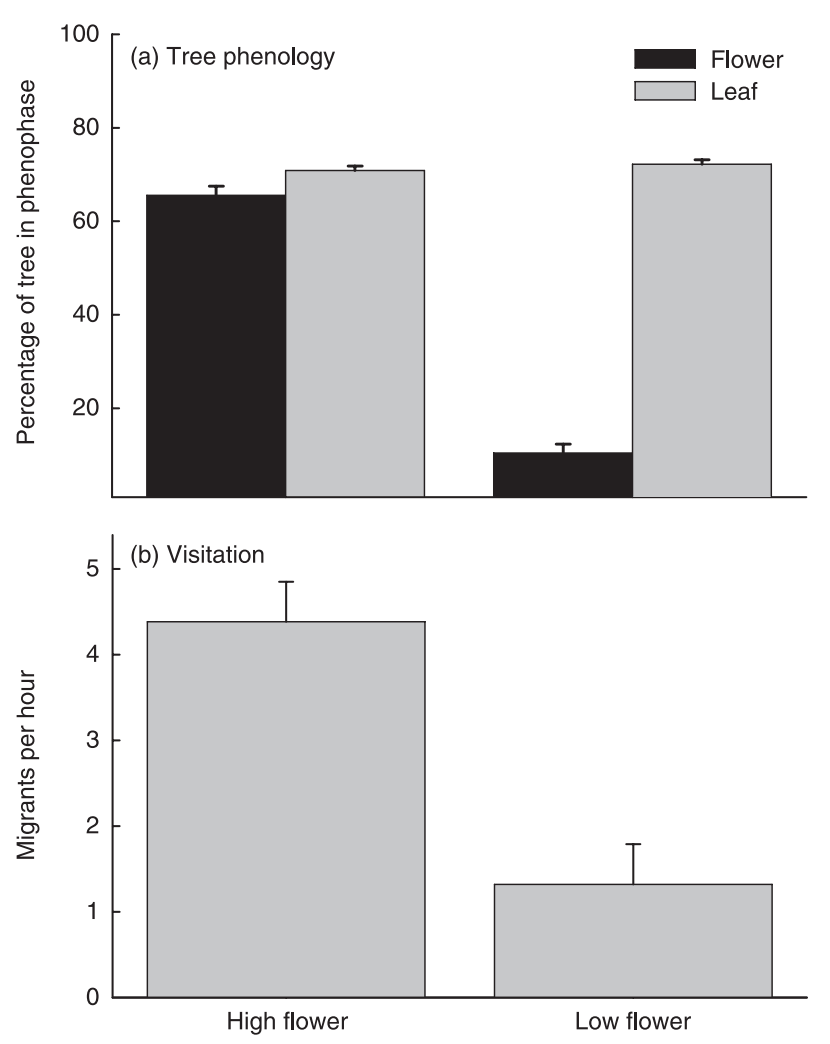

Fig. 5. Migrant visitation reflects differences in flower cues. Flower manipulation significantly altered flowering, but not leaf phenology (a), and resulted in reduced visitation by migrants (b). Columns represent estimated marginal means with standard errors after controlling for date.

arthropod herbivory and the production of chemical defenses to combat herbivory, represent significant costs (Agren \& Schemske 1993; Agrawal, Strauss \& Stout 1999), the phenology of honey mesquite may have evolved to exploit migrants as a natural insecticide (e.g. Marquis \& Whelan 1994). Indeed, birds may significantly reduce the costs of arthropod herbivory, increasing survival and reproduction of host plants (reviewed in Schmitz, Hambäck \& Beckerman 2000). That honey mesquite had the greatest abundance of arthropods (Fig. 3), and $>25 \%$ of the diet of migrants consisted of herbivorous insects, suggests such a possibility. The extreme abundance and concentration of migrants during spring migration may create a positive feedback loop whereby migrants reduce the costs of herbivory enabling honey mesquite trees to invest more in reproduction, producing more flowers, and thus a stronger signal to attract more migrants. In either case, the close tie between the timing and distribution of Neotropical migrants and the flowering phenology of honey mesquite suggests a strong co-evolutionary relationship.

Similar to the macrohabitat patterns, migrants preferred honey mesquite to other tree species, and particularly honey mesquite with more flowers (Fig. 2). That migrants prefer trees with more flowers (Fig. 2) is not surprising given the greater availability of food (Fig. 4); indeed, there are many empirical studies demonstrating the ability of birds to track food availability (Morris et al. 1958; Hildén 1965; MacArthur \& Pianka 1966; Zach \& Falls 1976; Hutto 1980, 1981, 1985b; Yard et al. 2004). Surprisingly, experimental tests of the importance of food availability in stopover decisions have failed to find a causal relationship (e.g. Hutto 1990); however, our data suggest an important distinction. Previous experiments altered food availability without changing the proximate cues birds rely upon to select appropriate habitats (Hutto 1990). Here we directly manipulated one settlement cue, flower phenology, and show migrants prefer honey mesquite trees with more flowers independent of other vegetative cues (Fig. 5) or actual food availability. Alternatively, by manipulating flower abundance, we may have inadvertently reduced arthropod abundance, leading to changes in migrant habitat preferences based on food availability and not flower phenology; however, this is unlikely. First, although flower availability likely influences the distribution of pollinating arthropods, a minor component of migrant diet, herbivorous arthropod are more dependent on leaf phenology (e.g. Murakami et al. 2007), which was unchanged (Fig. 5a). Second, migrants primarily persist on small cryptic arthropods, thus even if we did alter food availability, it is unlikely that birds could directly assess differences before visiting each tree. Indeed, the failure of previous studies to affect migrant habitat preferences by altering food availability (e.g. Hutto 1990) may reflect the importance of arthropod behaviours in determining which cues birds use to select stopover locations. Still, any accidental change to arthropod abundance may have been advertised via public information (e.g. Doligez et al. 2004), but given that migrants tended to arrive and forage alone suggests otherwise, and highlights the potential importance of vegetative cues in selecting foraging locations.

\section{Conclusion}

In the western USA, Neotropical migrants and their riparian migratory corridors are topics of conservation concern (Heglund \& Skagen 2005; van Andel \& Aronson 2006); yet little is known about the factors limiting migratory bird populations, particularly as it pertains to the ecology of migration. Given the strong correlation between honey mesquite flowering phenology and migrant populations at the macrohabitat level, as well as experimental and observational evidence of preference for flowering honey mesquite at the microhabitat level, it appears that the flowering phenology of honey mesquite is an important settlement cue for Neotropical migrant birds. That the flowering phenology of honey mesquite is a reliable indicator of food availability indicates the importance of this cue for migrant populations, at least along the Colorado River. It remains unclear how the phenology of honey mesquite or other tree species may influence migratory behaviours along other important migratory corridors that differ geographically, have different migratory peaks, and support different population and species assemblages (Skagen et al. 2005; Paxton et al. 2007). Furthermore, preferences based on proximate vegetative cues that likely 
respond independently from ultimate selective pressures acting on migratory timing or food availability, highlight the potential for this system to transform into an ecological trap (Robertson \& Hutto 2006). Future research should focus on the generality of flowering phenology as a settlement cue and how anthropogenic change, such as climate change and invasion by exotic tree species, may alter flower cues, migrant preference, and food availability independently to impact migrant populations.

\section{Acknowledgements}

We thank K. Decker, G. Johnson, C. Kirkpatrick, A. Chalfoun, M. Kearsley, S. Skagen, V. Salewski and an anonymous reviewer for comments and support, and numerous field assistants for their hard work. We also thank D. Gilbert, K. Blair, B. Zaun and M. Hawks with the US Fish and Wildlife Service and E. Sherbrooke with Univ. of Arizona for providing logistical support. This work was supported by funding to CVR from the US Geological Survey (SBSC and Invasive Species programs) and US Fish and Wildlife Service.

\section{References}

Agrawal, A.A., Strauss, S.Y. \& Stout, M.J. (1999). Costs of induced responses and tolerance to herbivory in male and female fitness components of wild radish. Evolution, 53, 1093-1104.

Agren, J. \& Schemske, D.W. (1993). The cost of defense against herbivores an experimental study of trichome production in Brassica rapa. American Naturalist, 141, 338-350.

Bell, G.W., Hejl, S.J. \& Verner, J. (1990). Proportional use of substrates by foraging birds: model considerations on first sightings and subsequent observations. Studies in Avian Biology, 13, 161-165.

Bradley, D.W. (1985). The effects of visibility bias on time-budget estimates of niche breadth and overlap. Auk, 102, 493-499.

DeLong, J.P., Cox, S.W. \& Cox, N.S. (2005). A comparison of avian use of highand low-elevation sites during autumn migration in central New Mexico. Journal of Field Ornithology, 76, 326-333.

Doligez, B., Part, T., Danchin, E., Clobert, J. \& Gustafsson, L. (2004). Availability and use of public information and conspecific density for settlement decisions in the collared flycatcher. Journal of Animal Ecology, 73, 75-87.

Fretwell, S.D. (1972). Populations in a Seasonal Environment. Princeton University Press, Princeton, New Jersey.

Fretwell, S.D. \& Lucas, H.L. Jr (1970). On territorial behavior and other factors influencing habitat distribution in birds. Acta Biotheoretica, 19, 16-36.

Heglund, P.J. \& Skagen, S.K. (2005). Ecology and physiology of en route Nearctic-Neotropical migratory birds: call for collaboration. Condor, 107, 193-196.

Hertz, P.E., Remsen, J.V. Jr \& Zones, S.I. (1976). Ecological complementarity of three sympatric parids in California oak woodland. Condor, 78, 307-316.

Hildén, O. (1965). Habitat selection in birds: review. Annales Zoologici Fennici, 2, 53-75.

Houston, A.I. (1998). Models of optimal avian migration: state, time and predation. Journal of Avian Biology, 29, 395-404.

Hutto, R.L. (1980). Winter habitat distribution of migratory land birds in western Mexico, with special reference to small, foliage-gleaning insectivores. Migrant Birds in the Neotropics: Ecology, Behavior, Distribution, and Conservation (eds A. Keast and E.S. Morton), pp. 181-203. Random House (Smithsonian Institution Press), Washington, DC.

Hutto, R.L. (1981). Temporal patterns of foraging activity in some wood warblers in relation to the availability of insect prey. Behavioral Ecology and Sociobiology, 9, 195-198.

Hutto, R.L. (1985a). Habitat selection by nonbreeding, migratory land birds. Habitat Selection in Birds (ed. M.L. Cody), pp. 455-476. Academic Press, Inc., New York.

Hutto, R.L. (1985b). Seasonal Changes in the habitat distribution of transient insectivorous birds in south-eastern Arizona: competition mediated? Auk, 102, 120-132.

Hutto, R.L. (1990). Studies of foraging behavior: central to understanding the ecological consequence of variation in food abundance. Studies in Avian Biology, 13, 389-390.
Hutto, R.L., Pletschet, S.M. \& Hendricks, P. (1986). Fixed-radius point count method for nonbreeding and breeding season use. Auk, 103, 593-602.

Johnson, M.D. (2000). Evaluation of an arthropod sampling technique for measuring food availability for forest insectivorous birds. Journal of Field Ornithology, 71, 88-109.

Lima, S.L. \& Dill, L.M. (1990). Behavioral decisions made under the risk of predation: review and prospectus. Canadian Journal of Zoology, 68, 619-640.

Lind, J. \& Cresswell, W. (2006). Anti-predation behaviour during migration; the benefit of studying multiple behavioral dimensions. Journal of Ornithology, 147, 310-316.

Lindström, A. (1989). Finch flock size and risk of hawk predation at migratory stopover site. Auk, 106, 225-232.

Loria, D.E. \& Moore, F.R. (1990). Energy demands of migration on red-eyed vireos, Vireo olivaceus. Behavioral Ecology, 1990, 24-35.

MacArthur, R.H. \& Pianka, E.R. (1966). On the optimal use of patchy environment. American Naturalist, 100, 603-609.

Marques, E.S.D., Price, P.W. \& Cobb, N.S. (2000). Resource abundance and insect herbivore diversity on Fabaceous desert plants. Environmental Entomology, 29, 696-703.

Marquis, R.J. \& Whelan, C.J. (1994). Insectivorous birds increase the growth of white oak through consumption of leaf-chewing insects. Ecology, 75, 2007-2014

Marra, P.P., Hobson, K.A. \& Holmes, R.T. (1998). Linking winter and summer events in migratory bird by using stable isotopes. Science, $\mathbf{2 8 2}$, 1884-1886.

Moody, D.T. (1970). A method for obtaining food samples from insectivorous birds. Auk, 81, 579 .

Moore, F.R. \& Aborn, D.A. (2000). Mechanisms of en route habitat selection: how do migrants make habitat decisions during stopover? Studies in Avian Biology, 20, 34-42.

Moore, F.R. \& Yong, W. (1991). Evidence of food-based competition among passerine migrants during stopover. Behavioral Ecology and Sociobiology, 28, 85-90.

Moore, F.R., Kerlinger, P. \& Simons, T.R. (1990). Stopover on Gulf coast barrier island by spring trans-Gulf migrants. Wilson Bulletin, 102, 487500 .

Moore, F.R., Gauthreaux, S.A. Jr, Kerlinger, P. \& Simons, T.R. (1995). Habitat requirements during migration: important link in conservation. Ecology and Management of Neotropical Migratory Birds (eds T.E. Martin \& D.M. Finch), pp. 121-144. Oxford University Press, New York.

Moore, F.R., Smith, R.J. \& Sandberg, R. (2005). Stopover ecology of intercontinental migrant. Birds of Two Worlds: The Ecology and Evolution of Migration (eds R. Greenberg \& P.P. Marra), pp. 251-261. John Hopkins University Press, Maryland.

Morris, R.F., Cheshire, W.F., Miller, C.A. \& Mott, D.G. (1958). The numerical response of avian and mammalian predators during gradation of spruce budworm. Ecology, 39, 487-494.

Murakami, M., Hirao, T. \& Ichie, T. (2007). Comparison of lepidopteran larval communities among tree species in temperate deciduous forest, Japan. Ecological Entomology, 32, 613-620.

Newton, I. (2006). Can conditions experienced during migration limit the population levels of birds? Journal of Ornithology, 147, 146-166.

Paxton, K.L., van Riper, C. III, Theimer, T.C. \& Paxton, E.H. (2007). Spatial and temporal migration patterns of Wilson's warbler (Wilsonia pusilla) in the southwest as revealed by stable isotopes. Auk, 124, 162-175.

Petit, D.R. (2000). Habitat use by landbirds along Nearctic-Neotropical migration routes: implications for conservation of stopover habitats. Studies in Avian Biology, 20, 15-33.

Piersma, T. (1990). Pre-migratory 'fattening' usually involves more than the deposition of fat alone. Ringing and Migration, 11, 113-115.

Poulin, B., Lefebvre, G. \& McNeil R. (1994). Effect and efficiency of tartar emetic in determining the diet of tropical land birds. Condor, 96, 98104.

Robertson, B.A. \& Hutto, R.L. (2006). A framework for understanding ecological traps and an evaluation of existing evidence. Ecology, 87, 1075-1085.

Rosenberg, K.V. \& Cooper, R.J. (1990). Approaches to avian diet analysis. Studies in Avian Biology, 13, 80-90.

Schmitz, O.J., Hambäck, P.A. \& Beckerman, A.P. (2000). Trophic cascades in terrestrial systems: review of the effects of carnivore removals on plants. American Naturalist, 155, 141-153.

Sillet, T.S. \& Holmes, R.T. (2002). Variation in survivorship of migratory songbird throughout its annual cycle. Journal of Animal Ecology, 71, 296-308.

Skagen, S.K., Kelly, J.F., van Riper, C., Hutto, R.L., Finch, D.M., Krueper, 
D.J. \& Melcher, C.P. (2005). Geography of spring landbird migration through riparian habitats in Southwestern North America. Condor, 107, 212-227.

Sturman, W.A. (1968). The foraging ecology of Parus atricapillus and P. rufescens in the breeding season, with comparisons with other species of Parus. Condor, 70, 309-322.

Tomback, D.F. (1975). An emetic technique to in- vestigate food preferences. Auk, 92, 581-583.

Van Andel, J. \& Aronson, J. (2006). Restoration Ecology: The New Frontier. Blackwell Publishing, Maldon, Massachusetts.

van Riper, C. III. (1980). The phenology of the dryland forest of Mauna Kea,
Hawaii, and the impact of recent environmental perturbations. Biotropica, 12, 282-291.

Yard, H.K., van Riper, C. III, Brown, B.T. \& Kearsley, M.J. (2004). Diets of insectivorous birds along the Colorado River in Grand Canyon, Arizona. Condor, 106, 106-115.

Zach, R. \& Falls, B.J. (1976). Ovenbirds (Aves:Parulidae) hunting behavior in patchy environment: an experimental study. Canadian Journal of Zoology, 54, 1863-1879.

Received 4 March 2008; accepted 18 July 2008

Handling Associate Editor: Simon Butler 